\title{
0 novo processo eletrônico de editoração do JBPML
}

A partir de novembro de 2008, o JBPML apresenta uma grande novidade: passa a integrar o grupo de revistas científicas que contam com processo de editoração eletrônica. Trata-se de um sistema on-line, cobrindo todos os trâmites editoriais de publicações científicas, desde submissão, recepção, encaminhamento aos revisores, devolução aos autores para eventuais correções sugeridas pelos revisores, envio para correções ortográficas e de normas, envio ao tradutor e ao diagramador. O sistema selecionado foi o Sistema de Gestão de Publicações (SGP), especialmente desenvolvido para publicações científicas.

Diferentemente de outros sistemas, neste a revisão é realizada em regime duplo-cego, ou seja, os autores desconhecem os revisores e vice-versa, atendendo às mais rigorosas normas científicas exigidas pelos mais importantes órgãos nacionais e internacionais de indexação de periódicos científicos para uma melhor classificação.

Também é possível fazer o acompanhamento completo e o rastreamento de artigos durante todo o processo de avaliação dos trabalhos científicos, reduzindo o tempo desde a submissão até a aprovação final e a publicação. Qualquer autor, revisor ou editor pode, em poucos segundos, saber em que posição do trâmite está o artigo. Tudo de forma segura e confiável.

A inclusão do JBPML no grupo das revistas eletrônicas traz a necessidade de cadastramento, também via eletrônica, de todos os revisores, bem como os obriga a obter alguma familiaridade com o sistema de informática utilizado. Sendo um programa bastante amigável e similar aos já utilizados por outras publicações científicas, temos certeza de que todos os nossos colaboradores rapidamente estarão usufruindo dos benefícios destes recursos.

O nível de acesso para submissão de trabalhos é simples. O primeiro passo é realizar o cadastro no SGP do JBPML, e para isso basta acessar a página http://www.jbpml.org.br/sgp. A partir do cadastro é possível iniciar o processo de submissão de artigos.

Ser autor e revisor do JBPML ficou mais atraente e simples. 